\title{
Pengaruh Penggunaan Pati Kentang (Solanum tuberosum) Termodifikasi Asetilasi- Oksidasi sebagai Gelling agent terhadap Stabilitas Gel Natrium Diklofenak
}

\author{
Adeltrudis Adelsa Danimayostu*, Nilna Maya Shofiana, Dahlia Permatasari \\ Jurusan Farmasi, Fakultas Kedokteran, Universitas Brawijaya, Indonesia
}

INFO ARTIKEL

Sejarah artikel:

Penerimaan naskah:

12 Oktober 2017

Penerimaan naskah

revisi: 18 Desember

2017

Disetujui untuk

dipublikasikan: 28

Desember 2017

\section{Kata kunci :}

Pati kentang, modifIkasi asetilasi

- oksidasi, gel

natrium diklofenak

\section{A B S T R A K}

Gel merupakan sistem semipadat yang dibuat dari partikel anorganik yang kecil atau molekul organik yang besar, terpenetrasi oleh suatu cairan. Gelling agent merupakan komponen polimer yang mempunyai berat molekul tinggi dan merupakan gabungan dari beberapa molekul dan lilitan dari polimer yang akan memberikan sifat kental pada gel. Pati kentang memiliki nilai swelling power dan viskositas tinggi dibandingkan dengan pati lainnya, yang keduanya mempunyai peran penting terhadap fungsi pati sebagai gelling agent. Modifikasi asetilasi-oksidasi mengakibatkan terjadinya peningkatan viskositas dan kejernihan pada gel yang dihasilkan. Penelitian ini bertujuan untuk menganalisis pengaruh pemberian pati kentang (Solanum tuberosum) termodifikasi asetilasi-oksidasi sebagai Gelling agent pada stabilitas gel yang mengandung natrium diklofenak. Studi eksperimental menggunakan metode uji stabilitas real time dan freeze thaw dilakukan terhadap gel natrium diklofenak. Sampel dibagi menjadi empat kelompok yaitu kelompok gel "pati terasetilasi-oksidasi", kelompok gel "pati terasetilasi", kelompok gel "pati teroksidasi" dan kelompok gel "pati alami". Variabel yang diukur pada penelitian ini adalah stabilitas fisik dan kimia dari gel natrium diklofenak yang dihasilkan. Hasil penelitian menunjukkan bahwa stabilitas fisik antara gel pati terasetilasi-oksidasi dengan gel pati terasetilasi, gel pati teroksidasi dan gel pati alami memliki nilai yang berbeda bermakna (Oneway Anova, $\mathrm{p}<0,05$ ). Tidak terjadinya perubahan stabilitas fisik dan kimia pada semua kelompok gel setelah uji stabilitas real time dan freeze-thaw pada semua evaluasi sediaan gel (Uji T Berpasangan, p>0,05). Namun demikian, terjadi perubahan pada daya sebar gel pada semua kelompok setelah uji stabilitas freeze-thaw (Uji Wilcoxon, p<0,05). Kesimpulan dari penelitian ini adalah pati kentang (Solanum tuberosum) modifikasi asetilasi-oksidasi dapat mempertahankan stabilitas gel natrium diklofenak berdasarkan karakteristik gel yaitu organoleptik, viskositas, $\mathrm{pH}$, daya sebar dan kadar natrium diklofenak..

\section{The Effect of Acetylation - Oxidation Modified Potato Starch (Solanum tuberosum) as Gelling agent on Diclofenac Sodium Gel Stability}

\section{Keywords:}

Potato starch, acetylation oxidation modified, diclofenac sodium, gel

\section{A B S T R A C T}

Gels are semisolid system consist of small inorganic particles or large organic molecules that penetrated by a fluid. The Gelling agent is a polymeric component having a high molecular weight and a combination of several molecules and windings of the polymer that give a viscous properties of the gel. Potato starch has higher swelling power and viscosity values than other starches, which both have an important role on the function of starch as a gelling agent. Acetylation - oxidation modification results in increasing of viscosity and clarity of gel. This study aimed to analyze the effect of potato starch (Solanum tuberosum) modified by acetylation-oxidation as a Gelling agent on the stability of gel containing diclofenac sodium. Experimental studies using real time stability and freeze thaw stability has been apllied to diclofenac sodium gel. The samples were divided into four groups: group gel "acetylation-oxidized starch", group gel "acetylated starch", group gel "oxidized starch" and gel "natural starch". The measured variables were physical and chemical stability of gel diclofenac sodium. The result of this research indicated that physical stability between acetylation-oxidized starch gel with acetylated starch gel, oxidized starch gel, and natural starch gel value were significantly different (oneway ANOVA, $p$ $<0.05)$. There were no changes in physical and chemical stability in all groups after real time and freeze - thaw stability (paired t test, $\mathrm{p}>0.05$ ). However, spreadability characteristics were significantly different in all groups after freeze - thaw stability test (Wilcoxon test, $\mathrm{p}<0.05$ ). It can be concluded that acetylation-oxidation modified potato starch was able to maintain the stability of sodium diclofenac sodium gel characteristic (organoleptic, viscosity, $\mathrm{pH}$, dispersive power and concentration of diclofenac sodium).

\footnotetext{
* Corresponding author Adeltrudis Adelsa Danimayostu, Jurusan Farmasi Fakultas Kedokteran Universitas Brawijaya, Jalan Veteran Malang 65145, Telp: +62341-551611, Fax: +62-341-565420. E-mail: elsa.adam@ub.ac.id.
} 


\section{Pendahuluan}

Gel merupakan sistem semipadat yang dibuat dari partikel anorganik yang kecil atau molekul organik yang besar, terpenetrasi oleh suatu cairan. ${ }^{1}$ Formulasi gel membutuhkan senyawa Gelling agent sebagai bahan pembentuk gel. Gelling agent atau bahan pembentuk gel merupakan komponen polimer yang mempunyai berat molekul tinggi dan merupakan gabungan dari beberapa molekul dan lilitan dari polimer yang akan memberikan sifat kental pada gel. Molekul-molekul polimernya berikatan melalui ikatan silang sehingga membentuk struktur jaringan tiga dimensi dengan molekul pelarut yang terperangkap dalam jaringan ini. ${ }^{2}$

Pati adalah cadangan karbohidrat yang banyak terdapat di tanaman dan merupakan bahan yang berharga pada industri makanan karena banyak digunakan sebagai pengental, gelling agent, bulking agent dan water retention agent. $^{3}$ Pati kentang memiliki nilai swelling power dan viskositas tinggi dibandingkan dengan pati lainnya, yang keduanya mempunyai peran penting terhadap fungsi pati sebagai gelling agent. Pati terdiri dari dua polisakarida yaitu amilosa linear dan amilopektin bercabang. Pati alami mempunyai beberapa permasalahan yang berhubungan dengan retrogradasi, stabilitas rendah, dan ketahanan pasta yang rendah maka untuk memperbaiki keterbatasan tersebut dilakukan modifikasi pati baik secara fisika maupun secara kimia. ${ }^{4}$

Metode modifikasi pati yang banyak digunakan adalah asetilasi, metode ini merupakan reaksi esterifikasi menggunakan asam asetat. Reaksi asetilasi menggantikan gugus hidroksil pada pati alami dengan gugus asetil. Penggantian dengan gugus asetil tersebut menyebabkan berkurangnya kekuatan ikatan antara molekul pati dan mengubah sifat dari pati. ${ }^{5}$ Modifikasi pati secara oksidasi menghasilkan pati dengan sifat gel yang lebih jernih, kekuatan regangan dan viskositasnnya lebih rendah. Pati yang teroksidasi diperoleh dengan cara mengoksidasi pati dengan senyawa-senyawa pro-oksidan yang dilakukan pada $\mathrm{pH}$ tertentu, suhu dan waktu reaksi yang sesuai. Pati dapat dioksidasi dengan aktivitas dari beberapa zat pengoksidasi dalam suasana asam, netral atau larutan alkali. ${ }^{6}$ Kombinasi modifikasi asetilasi-oksidasi mengakibatkan pati memiliki swelling power lebih tinggi dari pati alami, pati oksidasi, pati asetilasi serta pati dengan modifikasi acid thin. Kelarutan yang dimiliki pati modifikasi kombinasi asetilasioksidasi juga mengalami peningkatan dibandingkan dengan pati alami dan pati modifikasi tunggal asetilasi, oksidasi serta acid thin. ${ }^{7}$

Dari penjelasan di atas, telah terbukti bahwa pati termodifikasi asetilasi-okidasi dapat meninkatkan viskositas dan kestabilan dari pati. Apabila dihubungkan dengan fungsinya sebagai gelling agent, maka penggunaan pati kentang termodifikasi asetilasi-oksidasi dapat meningkatkan kestabilan gel. Oleh karena itu, perlu dilakukan penelitian untuk menganalisis pengaruh pemberian pati kentang (Solanum tuberosum) termodifikasi asetilasi-oksidasi sebagai Gelling agent pada stabilitas gel yang mengandung natrium diklofenak.

\section{Metode}

\section{Bahan Penelitian}

Bahan-bahan yang digunakan pada penelitian ini antara lain pati kentang (Solanum tuberosum), asam asetat, $\mathrm{NaOCl}, \mathrm{NaOH}, \mathrm{HCl}$ 0,5 N, KOH 0,5 M, phenolphthalein, isopropil alkohol, metil paraben, propilen glikol, parfum lemon, dan akuades. Natrium diklofenak dari Universitas Muhammadiyah Malang.

\section{Modifikasi Pati Kentang Oksidasi}

Modifikasi oksidasi pati kentang pada penelitian dilakukan dengan mencampurkan pati dan akuades dengan perbandingan $1: 2$, kemudian $\mathrm{pH}$ suspensi pati tersebut disesuaikan menjadi 9,5 menggunakan $\mathrm{NaOH} 1 \mathrm{M}$. Selanjutnya ditambahkan $\mathrm{NaOCl}$ (sodium hipoklorit) pada suspensi pati dengan dijaga $\mathrm{pH}$ larutan dalam rentang 9,09,5 . Kemudian $\mathrm{pH}$ suspensi pati disesuaikan menjadi 7 dengan cara dicuci menggunakan akuades kemudian dikeringkan menggunakan oven dengan suhu $45^{\circ} \mathrm{C}$ selama 12 jam. $^{7}$

\section{Modifikasi Pati Kentang Asetilasi}

Modifikasi asetilasi pati kentang pada penelitian dilakukan dengan merendam pati kentang sebanyak 150 gram dalam $450 \mathrm{ml}$ akuades (1:3). Hal ini dilakukan untuk memudahkan proses tercampurnya pati kentang dengan reagen asam asetat. Larutan asam asetat dan larutan $\mathrm{NaOH}$ $1 \mathrm{M}$ ditambahkan secara bersamaan sebanyak $0,9 \mathrm{ml} \mathrm{ke}$ dalam pati kentang yang telah direndam sebelumnya sedikit demi sedikit sambil diaduk dan dilakukan perendaman selama 90 menit. Nilai $\mathrm{pH}$ larutan pati kentang tersebut dipertahankan dalam rentang 8 - 8,4 kemudian ditambahkan larutan $\mathrm{HCl} 0,5 \mathrm{~N}$ sampai $\mathrm{pH}$ larutan mencapai kurang lebih 6. Endapan pati tersebut dicuci menggunakan akuades hingga mencapai $\mathrm{pH} \mathrm{7,} \mathrm{kemudian} \mathrm{pati} \mathrm{tersebut} \mathrm{dikeringkan}$ pada suhu $40^{\circ} \mathrm{C}$ selama $12 \mathrm{jam}^{8}$

\section{Modifikasi Pati kentang Asetilasi - Oksidasi}

Pada modifikasi kombinasi ini dilakukan modifikasi seperti yang telah dijelaskan pada poin sebelumnya dimana dilakukan modifikasi pati kentang secara oksidasi terlebih dahulu. Selanjutnya pati kentang teroksidasi tersebut langsung dimodifikasi kembali dengan metode asetilasi. ${ }^{7,8}$

\section{Evaluasi Modifikasi Pati Kentang Termodifikasi Oksidasi}

Uji persen karboksil pada penelitian ini dilakukan dengan mencampurkan $0,5 \mathrm{~g}$ pati kentang yang telah dimodifikasi oksidasi dalam $60 \mathrm{ml}$ akuades, kemudian suspensi ini dipanaskan selama 10 menit dengan dilakukan pengadukan yang konstan. Selanjutnya suspensi dititrasi dengan menggunakan $\mathrm{NaOH}$ 0,025 $\mathrm{M}$ setelah sebelumnya ditetesi dengan indikator phenolphthalein 2 tetes. ${ }^{9}$ 


\section{Evaluasi Modifikasi Pati Kentang Termodifikasi Asetilasi}

Uji persen asetil dan derajat substitusi (Degree of Subtitution/DS) pada penelitian ini dilakukan dengan menimbang pati kentang terasetilasi sebanyak 1 gram dan dilarutkan dalam etanol $75 \% 50 \mathrm{ml}$ selama 30 menit pada suhu $50^{\circ} \mathrm{C} .^{8}$ Campuran tersebut didinginkan pada suhu ruang, lalu ditambahkan $40 \mathrm{ml} \mathrm{KOH} \mathrm{0,5} \mathrm{M} \mathrm{dan} \mathrm{disimpan}$ pada suhu ruang selama 72 jam. Kemudian kelebihan alkali pada campuran pati ditritasi dengan $\mathrm{HCl} 0,5 \mathrm{M}$ dan menggunakan phenolphthalein sebagai indikator. Setelah itu campuran pati kentang ditritasi kembali dengan $\mathrm{HCl} 0,5 \mathrm{M} .{ }^{8}$

\section{Proses Pembuatan Gel}

Tahap pembuatan gel natrium diklofenak dengan Gelling agent pati termodifikasi ini dilakukan dengan melarutkan natrium diklofenak dengan menggunakan isopropil alkohol dalam beaker glass sambil dilakukan pengadukan. Kemudian pada wadah yang lain, metil paraben dilarutkan dalam propilen glikol hingga terlarut sempurna. Selanjutnya larutan natrium diklofenak dicampurkan dengan larutan metil paraben. Tahapan berikutnya adalah pembuatan basis gel, dimana basis gel dibuat dengan mencampurkan pati kentang termodifikasi dengan sejumlah akuades dalam beaker glass dengan dipanaskan pada suhu $110^{\circ} \mathrm{C}$ kemudian diaduk hingga terbentuk gel. Selanjutnya campuran larutan pertama ditambahkan ke dalam basis gel yang telah terbentuk kemudian ditambahkan akuades hingga mencapai berat gel yang diinginkan. ${ }^{10}$

\section{Uji Stabilitas Freeze-Thaw}

Sediaan gel dimasukkan pada pot kaca tertutup rapat, kemudian dibekukan pada suhu $-18^{\circ} \mathrm{C}$ selama 20 jam setelah itu dicairkan pada suhu $25^{\circ} \mathrm{C}$ selama 4 jam (1 siklus), perlakuan tersebut diulang sebanyak 5 siklus. ${ }^{11}$

\section{Uji Stabilitas Real Time}

Sediaan diletakkan pada ruangan dengan suhu 30 $\pm 2^{\circ} \mathrm{C} / 25 \pm 2^{\circ} \mathrm{C}$ sesuai $\mathrm{ICH}$, namun pada penelitian ini dilakukan selama 30 hari. $^{12}$

\section{Pengukuran Kadar Natrium Diklofenak \\ - Preparasi Larutan Standar}

Larutan baku natrium diklofenak yang dilarutkan dengan akuades disiapkan dalam labu ukur, lalu larutan tersebut diencerkan menjadi beberapa konsentrasi yaitu 7,5; 10; 15; 20; dan 25 ppm. Selanjutnya absorbansi setiap konsentrasi diukur menggunakan spektrofotometer UV pada panjang gelombang maksimum.13

\section{- Preparasi Sampel}

Disiapkan sejumlah sampel gel natrium diklofenak, kemudian diencerkan $1 \mathrm{mg}$ gel natrium diklofenak dalam 10 $\mathrm{ml}$ akuades. Selanjutnya larutan sampel tersebut disonifikasi menggunakan sonikator selama 5 menit kemudian larutan tersebut dipipet sebanyak $2,5 \mathrm{ml}$ dalam labu takar lalu ditambahkan $25 \mathrm{ml}$ akuades.13 Tahap selanjutnya absorbansi larutan sampel tersebut di ukur absorbansinya pada spektrofotometer UV panjang dengan gelombang maksimum diklofenak 275,8 $\mathrm{nm}$. Hasil absorbansi yang diperoleh digunakan untuk menentukan kadar natrium diklofenak yang terdapat dalam sediaan gel menggunakan persamaan kurva baku.

\section{Uji Organoleptik}

Uji organoleptik pada penelitian ini dilakukan dengan pengamatan secara langsung bentuk, warna dan bau dari sediaan gel yang dibuat. ${ }^{14}$

\section{Uji pH}

Uji $\mathrm{pH}$ dilakukan dengan cara mencelupkan elektrode $\mathrm{pH}$ meter ke dalam setiap sediaan gel. Setelah elektrode tercelup, nyalakan $\mathrm{pH}$ meter kemudian didiamkan hingga layar pada $\mathrm{pH}$ meter menunjukkan angka yang stabil. ${ }^{15}$

\section{Uji Viskositas}

Uji viskositas pada penelitian ini dilakukan dengan menggunakan Brookfield viscometer. Sediaaan gel ditempatkan dalam Brookfield viscometer hingga spindel terendam. Diatur spindel dan kecepatan yang akan digunakan. Brookfield viscometer dijalankan, kemudian viskositas dari gel akan terbaca. ${ }^{15}$

\section{Uji Daya Sebar}

Uji daya sebar dilakukan dengan menimbang sediaan gel sebanyak 1 gram dan diletakkan pada plat kaca. Kemudian di atas plat kaca tersebut diletakkan plat kaca lain tanpa diberi tekanan, setelah itu diukur diameternya. Selanjutnya di atas plat kaca diletakkan beban sebesar 50 gram dan didiamkan selama 1 menit kemudian diukur diameter dari sediaan gel. Tahap selanjutnya dilakukan hal yang sama dengan beban 100, 200 dan 500 gram. ${ }^{16}$

\section{Analisa Data}

Analisis data statistik yang dilakukan menggunakan SPSS IBM 20. Data yang diperoleh dari hasil uji stabilitas dianalisis menggunakan uji parametrik Oneway ANOVA. Apabila persyaratan uji parametrik tidak terpenuhi, maka dilakukan uji non parametik Tukey. Selain uji Oneway ANOVA, juga dilakukan uji Paired T Test. Apabila data yang tidak terpenuhi persyaratan uji parametrik maka dilakukan uji non parametrik Wilcoxon.

\section{Hasil}

\section{Modifikasi Asetilasi Pati Kentang}

Berdasarkan hasil evaluasi modifikasi didapatkan nilai persen asetil dan DS dalam rentang yang sesuai dengan spesifikasi yaitu persen asetil sebesar 3-6\% dan DS sebesar 0,16-0,24 (Tabel 1). ${ }^{17}$

\section{Modifikasi Oksidasi Pati Kentang}

Berdasarkan hasil evaluasi modifikasi didapatkan nilai persen karboksil sesuai dengan spesifikasi yaitu persen karboksil $\geqslant 0,3 \%$ (Tabel 2). ${ }^{18}$ 
Tabel 1. Evaluasi Modifikasi Pati Kentang Terasetilasi

\begin{tabular}{lrc}
\hline & Persen asetil & DS \\
\hline Pati Kentang Terasetilasi & $4,932 \% \pm 0,015$ & $0,1952 \pm 0,011$ \\
\hline
\end{tabular}

Tabel 2. Evaluasi Modifikasi Pati Kentang Teroksidasi

\begin{tabular}{lc}
\hline & Persen Karboksil \\
\hline Pati Kentang Teroksidasi & $0,742 \% \pm 0,006$ \\
\hline
\end{tabular}

\section{Modifikasi Asetilasi - Oksidasi Pati Kentang}

Berdasarkan hasil evaluasi modifikasi didapatkan nilai persen asetil, DS dan persen karboksil sesuai dengan spesifikasi yaitu dalam rentang persen asetil sebesar 3-6\%, DS sebesar 0,16-0,24 (Tabel 3) dan persen karboksil $\geqslant$ $0,3 \%$ (Tabel 4).

Tabel 3. Evaluasi Persen Asetil dan DS Pati Kentang Terasetilasi-Oksidasi

\begin{tabular}{lccc}
\hline & & Persen asetil & DS \\
\hline Pati Kentang & Terasetilasi- & $4,294 \% \pm$ & $0,1688 \pm$ \\
oksidasi & & 0,021 & 0,015 \\
\hline
\end{tabular}

Tabel 4. Evaluasi Persen Karboksil Pada Pati Kentang Terasetilasi Oksidasi

\begin{tabular}{lc}
\hline & Persen Karboksil \\
\hline Pati Kentang Terasetilasi-oksidasi & $0,765 \% \pm 0,005$ \\
\hline
\end{tabular}

\section{Evaluasi pH Gel}

Berdasarkan nilai $\mathrm{pH}$ gel yang diukur pada hari ke0 , didapatkan nilai $\mathrm{pH} 7$ yang dimana $\mathrm{pH}$ tersebut dalam rentang $\mathrm{pH}$ sediaan topikal yaitu 4-8 (Tabel 5). ${ }^{19}$ Berdasarkan evaluasi pada hari ke-30 didapatkan tidak adanya perbedaan hasil nilai $\mathrm{pH}$ antara pengukuran nilai $\mathrm{pH}$ gel pada hari ke-0 pembuatan gel dengan nilai $\mathrm{pH}$ gel pengukuran hari ke-30 (Tabel 6). Pada pengukuran nilai $\mathrm{pH}$ setelah uji stabilitas freeze-thaw ini didapatkan nilai $\mathrm{pH}$ yang menurun dibandingkan dengan $\mathrm{pH}$ pada hari ke-0 pembuatan gel, akan tetapi nilai $\mathrm{pH}$ yang di dapatkan masih dalam rentang pH sediaan topikal, yaitu pH 4-8 (Tabel 7).

Tabel 5. Evaluasi pH Gel

\begin{tabular}{ccc}
\hline Fomula & Nilai pH & Spesifikasi \\
\hline F1 & $7,630 \pm 0,053$ & $4-8$ \\
\hline F2 & $7,227 \pm 0,025$ & $4-8$ \\
\hline F3 & $7,593 \pm 0,032$ & $4-8$ \\
\hline F4 & $7,177 \pm 0,030$ & $4-8$ \\
\hline
\end{tabular}

Keterangan : F1 = gel pati non modifikasi; F2 = gel pati teroksidasi; F3 = gel pati terasetilasi; F4 = gel pati terasetilasi - oksidasi

\section{Evaluasi Organoleptik Gel}

Berdasarkan hasil evaluasi segera setelah gel selesai dibuat, didapatkan perbedaan hasil antara gel yang menggunakan pati modifikasi dengan pati tanpa modifikasi sebagai gelling agent. Hasil gel pati tanpa modifikasi menunjukkan gel tersebut tidak sesuai dengan spesifikasi, sedangkan gel dengan Gelling agent pati modifikasi didapatkan gel sesuai dengan spesifikasi (Tabel 8).

Tabel 6. Evaluasi pH Gel Setelah Uji Stabilitas Realtime

\begin{tabular}{ccc}
\hline Formula & Hari Ke - O & Hari Ke - 30 \\
\hline F1 & $7,630 \pm 0,053$ & $7,534 \pm 0,039$ \\
\hline F2 & $7,227 \pm 0,025$ & $7,227 \pm 0,024$ \\
\hline F3 & $7,593 \pm 0,032$ & $7,577 \pm 0,007$ \\
\hline F4 & $7,177 \pm 0,030$ & $7,167 \pm 0,008$ \\
\hline
\end{tabular}

Keterangan: F1 = gel pati non modifikasi; F2 = gel pati teroksidasi; F3 = gel pati terasetilasi; F4 = gel pati terasetilasi - oksidasi.

Tabel 7. Evaluasi pH Gel Setelah Uji Stabilitas Freeze-Thaw

\begin{tabular}{ccc}
\hline Formula & pH Hari Ke - & pH Setelah Uji Freeze-Thaw \\
\hline F1 & $7,630 \pm 0,053$ & $7,051 \pm 0,039$ \\
\hline F2 & $7,227 \pm 0,025$ & $7,111 \pm 0,048$ \\
\hline F3 & $7,593 \pm 0,032$ & $7,459 \pm 0,005$ \\
\hline F4 & $7,177 \pm 0,030$ & $7,145 \pm 0,019$
\end{tabular}

Keterangan: F1 = gel pati non modifikasi; F2 = gel pati teroksidasi; F3 = gel pati terasetilasi; F4 = gel pati terasetilasi - oksidasi

Tabel 8. Evaluasi Organoleptik Gel Hari ke-0

\begin{tabular}{|c|c|c|c|}
\hline Formula & & Spesifikasi & Hasil \\
\hline \multirow[t]{4}{*}{ F1 } & Bentuk & Semi padat & Semi padat \\
\hline & Tekstur & Lembut & Lembut \\
\hline & Warna & Bening & Putih \\
\hline & Bau & Aroma lemon & Aroma lemon \\
\hline \multirow[t]{4}{*}{ F2 } & Bentuk & Semi padat & Semi padat \\
\hline & Tekstur & Lembut & Lembut \\
\hline & Warna & Bening & Bening \\
\hline & Bau & Aroma lemon & Aroma lemon \\
\hline \multirow[t]{4}{*}{$\mathbf{F 3}$} & Bentuk & Semi padat & Semi padat \\
\hline & Tekstur & Lembut & Lembut \\
\hline & Warna & Bening & Bening \\
\hline & Bau & Aroma lemon & Aroma lemon \\
\hline \multirow[t]{4}{*}{ F4 } & Bentuk & Semi padat & Semi padat \\
\hline & Tekstur & Lembut & Lembut \\
\hline & Warna & Bening & Bening \\
\hline & Bau & Aroma lemon & Aroma lemon \\
\hline
\end{tabular}

Keterangan: $\mathrm{F} 1=$ gel pati non modifikasi; $\mathrm{F} 2$ = gel pati teroksidasi; $\mathrm{F} 3=$ gel pati terasetilasi; F4 = gel pati terasetilasi - oksidasi

Berdasarkan evaluasi pada hari ke-30 didapatkan hasil organoleptik yang sesuai dengan spesifikasi gel pada semua gel dengan Gelling agent pati modifikasi, sedangkan gel dengan pati non modifikasi didapatkan hasil yang tidak sesuai dengan spesifikasi, dimana gel yang dihasilkan berwarna putih. Sedangkan pada evaluasi organoleptik, didapatkan perbedaan antara gel sebelum dan sesudah uji freeze-thaw, dimana didapatkan tekstur gel yang menggumpal setelah dilakukan uji freeze-thaw, yang berarti gel tersebut tidak sesuai dengan spesifikasi gel. 


\section{Evaluasi Daya Sebar Sediaan Gel}

Pada evaluasi ini didapatkan nilai daya sebar yang berbeda antar formula, dimana gel dengan pati teroksidasi memiliki nilai daya sebar tertinggi dibandingkan dengan gel dengan formula lain dan gel dengan pati terasetilasioksidasi mempunyai nilai yang terendah. Pada semua formula didapatkan nilai daya sebar yang sesuai dengan spesifikasi gel natrium diklofenak (Tabel 9). ${ }^{16}$

Tabel 9. Evaluasi Daya Sebar Gel

\begin{tabular}{ccccccc}
\hline Formula & \multicolumn{5}{c}{ Diameter (cm) } & Spesifi \\
& Lem & $20 \mathrm{~g}$ & $50 \mathrm{~g}$ & $100 \mathrm{~g}$ & $150 \mathrm{~g}$ & kasi \\
& peng & & & & & \\
& kaca & & & & & \\
\hline F1 & $5,4 \pm$ & $5,6 \pm$ & $6,0 \pm$ & $6,2 \pm$ & $6,4 \pm$ & $5-7 \mathrm{~cm}$ \\
& 0,1 & 0,1 & 0,1 & 0,1 & 0,1 & \\
\hline F2 & $5,7 \pm$ & $6,3 \pm$ & $6,5 \pm$ & $6,8 \pm$ & $7,1 \pm$ & $5-7 \mathrm{~cm}$ \\
& 0,1 & 0,1 & 0,1 & 0,1 & 0,1 & \\
\hline F3 & $4,2 \pm$ & $4,5 \pm$ & $4,9 \pm$ & $5,3 \pm$ & $5,8 \pm$ & $5-7 \mathrm{~cm}$ \\
& 0,1 & 0,1 & 0,1 & 0,1 & 0,1 & \\
\hline F4 & $4,0 \pm$ & $4,3 \pm$ & $4,7 \pm$ & $5,0 \pm$ & $5,3 \pm$ & $5-7 \mathrm{~cm}$ \\
& 0,1 & 0,1 & 0,1 & 0,1 & 0,2 & \\
& & &
\end{tabular}

Keterangan: F1 = gel pati non modifikasi; F2 = gel pati teroksidasi; F3 = gel pati terasetilasi; F4 = gel pati terasetilasi - oksidasi

Berdasarkan hasil evaluasi daya sebar setelah penyimpanan selama 30 hari tidak mengalami perbedaan nilai daya sebar gel natrium diklofenak sebelum dan sesudah penyimpanan (Tabel 10; 11).

Tabel 10. Diameter Daya Sebar Gel Setelah Uji Realtime

\begin{tabular}{ccc}
\hline Formula & \multicolumn{2}{c}{$\begin{array}{c}\text { Diameter }(\mathbf{c m}) \\
\text { pemberian beban 150 g) }\end{array}$} \\
\cline { 2 - 3 } & Hari Ke-0 & Hari Ke-30 \\
\hline F1 & $6,4 \pm 0,1$ & $6,4 \pm 0,2$ \\
\hline F2 & $7,1 \pm 0,1$ & $7,1 \pm 0,1$ \\
\hline F3 & $5,8 \pm 0,1$ & $5,8 \pm 0,1$ \\
\hline F4 & $5,3 \pm 0,2$ & $5,3 \pm 0,1$ \\
\hline
\end{tabular}

Keterangan: F1 = gel pati non modifikasi; F2 = gel pati teroksidasi; F3 = gel pati terasetilasi; F4 = gel pati terasetilasi - oksidasi

Tabel 11. Diameter Daya Sebar Gel Setelah Uji Freeze-Thaw

\begin{tabular}{ccc}
\hline Formula & \multicolumn{2}{c}{$\begin{array}{c}\text { Diameter }(\mathbf{c m}) \\
\text { pemberian beban 150 } \text { g) }\end{array}$} \\
\cline { 2 - 3 } & Hari Ke-0 & Hari Ke-30 \\
\hline F1 & $6,4 \pm 0,1$ & $3,0 \pm 0,1$ \\
\hline F2 & $7,1 \pm 0,1$ & $3,1 \pm 0,1$ \\
\hline F3 & $5,8 \pm 0,1$ & $3,0 \pm 0,0$ \\
\hline F4 & $5,3 \pm 0,2$ & $3,1 \pm 0,1$
\end{tabular}

Keterangan: F1 = gel pati non modifikasi; F2 = gel pati teroksidasi; F3 = gel pati terasetilasi; F4 = gel pati terasetilasi - oksidasi

Pada evaluasi daya sebar gel setelah melewati uji stabilitas freeze-thaw nilai daya sebar menurun, dimana nilai daya sebar yang didapat adalah $3 \mathrm{~cm}$.

\section{Evaluasi Viskositas Sediaan Gel}

Berdasarkan hasil evaluasi viskositas pada hari ke0 setelah pembuatan, didapatkan perbedaan viskositas antar formula. Viskositas gel dengan pati teroksidasi memiliki nilai viskositas terendah, kemudian gel dengan pati non modifikasi memiliki nilai viskositas di atas gel pati teroksidasi, selanjutnya gel dengan pati modifikasi asetilasi dan yang paling tinggi adalah gel dengan pati modifikasi kombinasi. Namun seluruh formula memenuhi spesifikasi sediaan (Tabel 12). ${ }^{15}$

Tabel 12. Evaluasi Viskositas Gel

\begin{tabular}{ccc}
\hline Formula & Nilai Viskositas (mPas) & Spesifikasi \\
\hline F1 & $2800 \pm 50 \mathrm{mPaS}$ & $2000-4000 \mathrm{mPaS}$ \\
\hline F2 & $2600 \pm 50 \mathrm{mPaS}$ & $2000-4000 \mathrm{mPaS}$ \\
\hline F3 & $3100 \pm 50 \mathrm{mPaS}$ & $2000-4000 \mathrm{mPaS}$ \\
\hline F4 & $3800 \pm 50 \mathrm{mPaS}$ & $2000-4000 \mathrm{mPaS}$
\end{tabular}

Keterangan: F1 = gel pati non modifikasi; F2 = gel pati teroksidasi; F3 = gel pati terasetilasi; F4 = gel pati terasetilasi - oksidasi

Berdasarkan hasil evaluasi viskositas setelah penyimpanan selama 30 hari tidak mengalami perbedaan nilai viskositas gel natrium diklofenak sebelum dan sesudah penyimpanan (Tabel 13). Pada evaluasi viskositas gel setelah uji stabilitas freeze-thaw ini didapatkan nilai viskositas yang lebih rendah dengan konsentrasi pada hari ke-0 setelah pembuatan gel natrium diklofenak (Tabel 14).

Tabel 13. Evaluasi Viskositas Setelah Uji Realtime

\begin{tabular}{ccc}
\hline Formula & Hari Ke-0 & Hari Ke-30 \\
\hline F1 & $2800 \pm 50 \mathrm{mPaS}$ & $2700 \pm 50 \mathrm{mPaS}$ \\
\hline F2 & $2600 \pm 50 \mathrm{mPaS}$ & $2600 \pm 50 \mathrm{mPaS}$ \\
\hline F3 & $3100 \pm 50 \mathrm{mPaS}$ & $3100 \pm 50 \mathrm{mPaS}$ \\
\hline F4 & $3800 \pm 50 \mathrm{mPaS}$ & $3800 \pm 50 \mathrm{mPas}$
\end{tabular}

Keterangan: F1 = gel pati non modifikasi; F2 = gel pati teroksidasi; F3 = gel pati terasetilasi; F4 = gel pati terasetilasi - oksidasi

Tabel 14. Evaluasi Viskositas Setelah Uji Freeze-Thaw

\begin{tabular}{ccc}
\hline Formula & Hari Ke-0 & Viskositas Setelah Uji Freeze-Thaw \\
\hline F1 & $2800 \pm 50 \mathrm{mPaS}$ & $2500 \pm 57,735 \mathrm{mPaS}$ \\
\hline F2 & $2600 \pm 50 \mathrm{mPaS}$ & $2400 \pm 57,735 \mathrm{mPaS}$ \\
\hline F3 & $3100 \pm 50 \mathrm{mPaS}$ & $2700 \pm 57,735 \mathrm{mPaS}$ \\
\hline F4 & $3800 \pm 50 \mathrm{mPaS}$ & $3700 \pm 57,735 \mathrm{mPaS}$
\end{tabular}

Keterangan: F1 = gel pati non modifikasi; F2 = gel pati teroksidasi; F3 = gel pati terasetilasi; F4 = gel pati terasetilasi - oksidasi

\section{Evaluasi Kadar Natrium Diklofenak Sediaan Gel}

Pada hasil evaluasi kadar natrium diklofenak didapatkan nilai konsentrasi pada semua formula yang dihasilkan sesuai dengan spesifikasi gel natrium diklofenak tersaji pada Tabel $15^{13}$ Hasil evaluasi kadar natrium diklofenak setelah penyimpanan selama 30 hari tidak mengalami perbedaan nilai konsentrasi natrium diklofenak sebelum dan sesudah penyimpanan. 
Tabel 15. Evaluasi Kadar Natrium Diklofenak Gel

\begin{tabular}{ccc}
\hline Formula & Kadar Natrium Diklofenak & Spesifikasi \\
\hline F1 & $9,1419 \pm 0,0326 \mathrm{ppm}$ & $9-11 \mathrm{ppm}$ \\
\hline F2 & $9,1093 \pm 0,0376 \mathrm{ppm}$ & $9-11 \mathrm{ppm}$ \\
\hline F3 & $9,1419 \pm 0,0188 \mathrm{ppm}$ & $9-11 \mathrm{ppm}$ \\
\hline F4 & $9,1093 \pm 0,0325 \mathrm{ppm}$ & $9-11 \mathrm{ppm}$ \\
\hline
\end{tabular}

Keterangan: F1 = gel pati non modifikasi; F2 = gel pati teroksidasi; F3 = gel pati terasetilasi; F4 = gel pati terasetilasi - oksidasi

Tabel 16. Evaluasi Kadar Natrium Diklofenak Gel Setelah Uji Realtime

\begin{tabular}{ccc}
\hline Formula & Hari ke 0 & Hari ke 30 \\
\hline F1 & $9,1419 \pm 0,0326 \mathrm{ppm}$ & $9,1093 \pm 0,1128 \mathrm{ppm}$ \\
\hline F2 & $9,1093 \pm 0,0376 \mathrm{ppm}$ & $9,1093 \pm 0,1128 \mathrm{ppm}$ \\
\hline F3 & $9,1419 \pm 0,0188 \mathrm{ppm}$ & $9,1419 \pm 0,0188 \mathrm{ppm}$ \\
\hline F4 & $9,1093 \pm 0,0325 \mathrm{ppm}$ & $9,1093 \pm 0,0187 \mathrm{ppm}$
\end{tabular}

Keterangan: F1 = gel pati non modifikasi; F2 = gel pati teroksidasi; F3 = gel pati terasetilasi; $\mathrm{F} 4=$ gel pati terasetilasi - oksidasi

Pada pengukuran kadar natrium diklofenak setelah uji stabilitas freeze-thaw ini didapatkan nilai konsentrasi natrium diklofenak yang sama dengan konsentrasi pada hari ke-0 setelah pembuatan gel natrium diklofenak (Tabel 17).

Tabel 17. Evaluasi Kadar Natrium Diklofenak Gel Setelah Uji Freeze-

\begin{tabular}{ccc}
\multicolumn{3}{c}{ Thaw } \\
\hline Formula & Hari ke-0 & Hari ke-30 \\
\hline F1 & $9,1419 \pm 0,0326 \mathrm{ppm}$ & $9,1419 \pm 0,0326 \mathrm{ppm}$ \\
\hline F2 & $9,1093 \pm 0,0376 \mathrm{ppm}$ & $9,1093 \pm 0,0376 \mathrm{ppm}$ \\
\hline F3 & $9,1419 \pm 0,0188 \mathrm{ppm}$ & $9,1419 \pm 0,0188 \mathrm{ppm}$ \\
\hline F4 & $9,1093 \pm 0,0325 \mathrm{ppm}$ & $9,1093 \pm 0,0325 \mathrm{ppm}$
\end{tabular}

Keterangan: F1 = gel pati non modifikasi; F2 = gel pati teroksidasi; F3 = gel pati terasetilasi; $\mathrm{F} 4=$ gel pati terasetilasi - oksidasi

Dari hasil uji Oneway ANOVA menunjukkan bahwa stabilitas fisik antara gel pati terasetilasi-oksidasi dengan gel pati terasetilasi, gel pati teroksidasi dan gel pati alami memliki nilai yang berbeda bermakna (Anova, $\mathrm{p}=0,000$ ). Sedangkan pada uji Paired $\mathrm{T}$ Test untuk mengetahui perubahan stabilitas fisik dan kimia pada semua kelompok gel setelah uji stabilitas real time dan freeze-thaw pada semua evaluasi sediaan gel (Uji T, p>0,05). Namun demikian, terjadi perubahan pada daya sebar gel pada semua kelompok setelah uji stabilitas freeze-thaw (Uji Wilcoxon, $\mathrm{p}=0,02$ ).

\section{Diskusi}

Pada evaluasi modifikasi pati terasetilasi dilakukan uji persen asetil dan DS, dimana didapatkan hasil persen asetil 4,932\% $\pm 0,015 \%$ dan sesuai spesifikasi $(3-6 \%) .{ }^{9}$ Pada perhitungan DS didapatkan hasil 0,1952 $\pm 0,011$ juga telah sesuai spesifikasi $(0,16-0,24)$. Evaluasi modifikasi pati teroksidasi dilakukan dengan perhitungan persen karboksil yang terdapat pada pati yang telah dimodifikasi. Pada evaluasi ini didapatkan hasil persen karboksil $0,742 \% \pm$ 0,006 . Persen karboksil pada pati teroksidasi ini sesuai dengan spesifikasi rentang jumlah karboksil dalam pati teroksidasi yaitu $\geq 0,3 \%{ }^{10}$
Pada pati terasetilasi-oksidasi dilakukan evaluasi modifikasi dengan menghitung persen asetil, DS (Degree of Substitution) dan persen karboksil. Pada evaluasi persen karboksil didapatkan persen karboksil sebesar 0,765 \pm $0,005 \%$. Hasil tersebut juga memenuhi spesifikasi jumlah persen karboksil yang ada pada pati modifikasi. Selanjutnya pada evaluasi persen asetil didapatkan hasil sebesar 4,293 \pm $0,021 \%$ sedangkan hasil DS (Degree of Substitution) didapatkan nilai sebesar $0,1688 \pm 0,015$. Hasil pengujian tersebut sesuai dalam spesifikasi jumlah persen asetil dan DS (Degree of Substitution). Akan tetapi, lebih rendahnya persen asetil dan DS (Degree of Substitution) disebabkan proses oksidasi sebelum dilakukannya proses asetilasi pada modifikasi ini. Pada proses asetilasi terjadi penggantian gugus hidroksil dari tiap unit anhidroglukosa pada molekul pati dengan gugus asetil, dimana pada proses oksidasi juga terjadi mengganti gugus hidroksil pada molekul pati dengan gugus karboksil, sehingga gugus hidroksil yang telah diganti dengan gugus karboksil tidak dapat digantikan dengan gugus asetil, dan mengakibatkan lebih rendahnya persen asetil dan DS (Degree of Substitution) pada pati terasetilasioksidasi dibanding dengan pati terasetilasi saja. ${ }^{10}$

Pada evaluasi organoleptik, gel dengan pati tanpa modifikasi didapatkan hasil gel dengan warna putih, bertekstur lembut, berbentuk semi padat dan beraroma lemon. Pada gel dengan pati modifikasi, baik modifikasi asetilasi, oksidasi dan asetilasi-oksidasi didapatkan hasil gel dengan warna bening, bertekstur lembut, berbentuk semi padat dan beraroma lemon. Ini menunjukkan bahwa gel dengan pati modifikasi memiliki hasil yang sesuai dengan spesifikasi yaitu berbentuk semi padat, berwarna bening, bertekstur lembut dan beraroma lemon. Kejernihan gel salah satunya disebabkan oleh penggantian gugus hidroksil dengan asetil dan karboksil. ${ }^{20}$

Evaluasi organoleptik juga dilakukan pada setelah dilakukan uji stabilitas real time dan freeze-thaw. Setelah dilakukan uji stabilitas real time selama 30 hari didapatkan hasil gel dengan bentuk semi padat, tekstur lembut, berwarna bening dan beraroma lemon kecuali gel dengan pati tanpa modifikasi, dimana gel yang dihasilkan berwarna putih. Hasil ini menunjukkan bahwa selama 30 hari uji stabilitas realtime, gel tidak mengalami perubahan secara organoleptik yang artinya gel yang dihasilkan stabil. Sedangkan pada uji stabilitas freeze-thaw, didapatkan perubahan tekstur pada semua gel yang dihasilkan. Gel yang telah mengalami uji stabilitas freeze-thaw memiliki tekstur gel yang menggumpal. Hal ini disebabkan penurunan kemampuan gel dalam menahan air rendah akibat penurunan suhu, sehingga menyebabkan kecenderungan molekul amilosa keluar dari granula pati yang telah pecah dan membentuk gumpalan. ${ }^{21}$

Evaluasi $\mathrm{pH}$ bertujuan untuk mengetahui keamanan suatu sediaan, terutama sediaan topikal. Idealnya sediaan topikal mempunyai nilai $\mathrm{pH}$ yang sama dengan $\mathrm{pH}$ kulit agar tidak terjadi iritasi pada permukaan kulit. Hasil $\mathrm{pH}$ yang didapatkan sesuai dengan spesifikasi $\mathrm{pH}$ pada sediaan 
gel. Gel merupakan sediaan topikal yang diaplikasikan di atas permukaan kulit, sehingga $\mathrm{pH}$ yang seharusnya dimiliki sediaan topikal adalah $\mathrm{pH}$ yang sesuai dengan $\mathrm{pH}$ kulit, yaitu $\mathrm{pH} 4-8 .{ }^{12}$

Hasil viskositas menunjukkan perbedaan pada setiap formula. Gel dengan pati teroksidasi memiliki viskositas terendah dan gel dengan pati terasetilasi-oksidasi memiliki viskositas tertinggi. Hal ini disebabkan substitusi gugus asetil pada gugus hidroksil pati berakibat pada peningkatan viskositas gel. ${ }^{8}$ Pada evaluasi daya sebar, didapatkan hasil yang berbeda pada setiap formula yang dihasilkan. Semua formula baik gel dengan pati tanpa modifikasi maupun pati modifikasi mempunyai daya sebar yang sesuai dengan spesifikasi gel. Daya sebar gel pati teroksidasi memiliki hasil tertinggi. Hal ini disebabkan pati teroksidasi menghasilkan gel yang memiliki viskositas yang rendah akibat proses oksidasi sehingga daya sebar yang dimiliki gel pati teroksidasi tinggi. ${ }^{6}$

Setelah dilakukan uji stabilitas real time dan freeze-thaw, daya sebar masing-masing formula diukur kembali. Pada uji stabilitas real time didapatkan hasil yang daya sebar yang tidak jauh berbeda dengan daya sebar pada awal titik pengukuran setelah gel dibuat. Sedangkan pada evaluasi daya sebar setelah uji stabilitas freeze-thaw didapatkan hasil yang berbeda, dimana hasil pengukuran menunjukkan nilai daya sebar yang rendah dan tidak memenuhi spesifikasi daya sebar gel yang baik. Pengaruh perbedaan suhu yang ekstrem selama penyimpanan menyebabkan kecenderungan amilosa bergabung dan membentuk gumpalan sehingga gel tidak homogen. ${ }^{21}$

Hasil kadar natrium diklofenak pada semua gel menunjukkan nilai yang memenuhi spesifikasi kadar zat aktif dalam sediaan gel yakni tidak kurang $90 \%$ dan tidak lebih dari $110 \%$ jumlah yang ditetapkan. Selain itu, pada pengukuran kadar natrium diklofenak setelah uji stabilitas real time dan freeze-thaw, hasil yang didapatkan tidak jauh berbeda dengan sebelum dilakukannya uji stabilitas. Hal ini menunjukkan bahwa kadar natrium diklofenak stabil dalam sediaan gel yang dihasilkan. ${ }^{13}$

Berdasarkan hasil penelitian tentang pengaruh penggunaan pati kentang (Solanum tuberosum) termodifikasi asetilasi-oksidasi sebagai Gelling agent terhadap stabilitas gel natrium diklofenak didapatkan kesimpulan bahwa pati kentang (Solanum tuberosum) modifikasi asetilasi-oksidasi dapat mempertahankan stabilitas gel natrium diklofenak berdasarkan karakteristik gel yaitu organoleptik, viskositas, $\mathrm{pH}$, daya sebar dan kadar natrium diklofenak.

\section{Daftar Pustaka}

1. Dirjen Badan POM. 1995. Farmakope Indonesia. Ed ke-4. Departemen Kesehatan Republik Indonesia. Jakarta.

2. Karsheva, M., S. Georgieva dan G. Birov. 2007. Flow Behavior Of Two Industrially Made Shampoos.
Journal of the University of Chemical Technology and Metallurgy, 40, 4, P.323-328.

3. Li S, Yingquan Z, Yimin W, Wei Z and Bo Z. 2014. Thermal, Pasting and Gel Textural of Properties of Commercial Starches from Different Botanical Sources. J Bioproces Biotechniq 4:4.

4. Lewicka Kamila, Przemyslaw S., and Piotr K. 2015. Chemical Modifications of Starch: Microwave Effect. International Journal of Polymer Science, Vol 2015.

5. Ayucitra, Aning. 2012. Preparation and Characterisation of Acetylated Corn Starches. International Journal of Chemical Engineering and Applications, Vol. 3, No. 3.

6. Koswara, S. 2009. Teknologi Modifikasi Pati. http://tekpan.unimus.ac.id/wpcontent/uploads/2013/07/TEKNOLOGIMODIFIKASI-PATI.pdf. Diakses pada tanggal 26 November 2015 pada pukul 19.00 WIB

7. Khan, K. H., T. M. Ali dan A. Hasnain. 2014. Effect of Chemical Modification on The Functional and Rheological Properties of Potato (Solanum tuberosum) Starches. The Journal of Animal \& Plant Sciences, 24(2), Hal: 550-555.

8. Teja, A.W., I. Sindi, A. Ayucitra, dan L.E.K. Setiawan. 2008. Karakteristik Pati Sagu dengan Modifikasi Asetilasi dan Cross-Linking. Jurnal Teknik Kimia Indonesia, Vol. 7 No. 3 Desember 2008: 836-843.

9. Anindya, A. S dan Hariyadi. 2014. Oksidasi Hancuran Singkong Menggunakan $\mathrm{H} 2 \mathrm{O} 2$ dan Asam Laktat dengan Katalisator Ferrous Sulfate Heptahydrate untuk Meningkatkan Baking Expansion. Jurnal Aplikasi Teknologi Pangan 3 (4) 2014

10. Baviskar, D.T., Y.A. Biranwar, K.R. Bare, V.B. Parik, M.K. Sapate, dan D.K. Jain. 2013. In Vitro and In Vivo Evaluation of Diclofenac Sodium Gel Prepared with Cellulose Ether and Carbopol 934P. Tropical Journal of Pharmaceutical Research August 2013; 12 (4): 489494, ISSN 1596-5996

11. Lee, MH, Baek, MH, Cha, DS, Park, HJ and Lim, ST. 2002. Freeze Thaw Stabilization of Sweet Potato Starch gel by Polysaccharide Gums. In: Food Hydrocolloids 16(2002) 345-352

12. ICH. 1996. Stability Testing: Photostability Testing Of New Drug Substances and Products Q1b. ICH Harmonised Tripartite Guideline.

13. Naveed, S. dan F. Qamar. 2014. UV Spectrophotometric Assay of Diclofeac Sodium Available Brands. Journal of Innovation in Pharmaceuticals and Biological Science. Vol. 1 (3), 92-96, 2014.

14. Titaley, S., Fatimawali dan Widya, A. L. 2014. Formulasi Dan Uji Efektifitas Sediaan Gel Ekstra Etanol Daun Mangrove Api-Api (Avicennia marina) Sebagai Antiseptik Tangan. Jurnal Ilmiah Farmasi UNSRAT Vol. 3 No. 2 Mei 2014 ISSN 2302 - 249399.

15. Septiani, S., N. Wathoni, dan S. R. Mita. 2011. Formulasi Sediaan Masker Gel Antioksidan dari 
Ekstrak Etanol Biji Melinjo (Gnetum gnemon Linn.). Jurnal Unpad. 1(1): 4-24

16. Garg, A., D. Aggarwal, S. Garg, and A. K. Sigla. 2002. Spreading of Semisolid Formulation: An Update. Pharmaceutical Tecnology. September: 84-102

17. Garcia, F.P, Judith P.M, Maria A.M, Luis B.P dan Alma D.R. 2012. Modification and Chemical Characterization of Barley Starch. International Journal of Applied Science and Technology. Vol. 2 No. 4; April 2012.

18. Ainun, J.N dan Purwiyanto Hariyadi, 2007. Pasta Pati Jagung Putih Waxydan Non-Waxy yang Dimodifikasi Secara Oksidasi Dan Asetilasi-Oksidasi. Jurnal llmu Pertanian Indonesia. Vol. 12 No 2.

19. Shukry,M. H dan Ghada F. 2013. Evaluation of Topical Gel Bases Formulated with Various Essential Oils for Antibacterial Activity against MethicillinResistant Staphylococcus Aureus. Tropical Journal of Pharmaceutical Research December 2013; 12 (6): 877884.

20. Sherry, X., Qiang L and Steve W. C. 2015. Starch Modification and Applications. Taylor \& Francis Group, LLC.

21. Cui, S. W. 2005. Food Carbohydrates: Chemistry, Physical Properties, and Application. CRC Press. Prancis 